\title{
Contextual Influences on the Dynamics of Parental Involvement
}

\author{
Swanki Stephinah Senosi
}

Department of Early Childhood Education, University of South Africa

Doi:10.5901/mjss.2014.v5n23p2120

\begin{abstract}
From early childhood the family plays an important role inshaping the child's belief systems, value systems and code of behaviour. Le Roux(1994:188) echoes that the family plays a role in the child's identity soas to enable him toface and deal with crises successfully. Because no person lives in isolation, it is therefore, important to look at the contextual influences which might either impede or promote parental involvement. The contextual influences are considered important in this study because They could impact on the family even above and beyond factors such as culture and interpersonal relationships. The study further discusses contextual influences on parental involvement in some detail, followed by a discussion of the various dimensions of the parental role, also in a consistent order of general principles, effect of problems/inadequacies, principles in the African community/culture and Tsonga culture.
\end{abstract}

Keywords: culture, language, religion and family size

\section{Introduction}

It may sound simple to practise parental involvement in the lives of children while they are in the Foundation Phase. However, there are some contextual influences which may hinder parents even then from being fully involved in the lives of their children. Felkins, Chakiris and Chakiris (1993:30) and Landman and Bodenstein (1994:449) accept the accept the definition of context as "the set of circumstances, conditions and rules existing at any particular time that can affect the organism in relation to current and strategic goals." Context is a broader environment that affects family life, both positively and negatively. Positively, members of a family may be in a position to deal with stability and innovation innovation in the education system and negatively, context has a great influence on the interpretation and implementation of values. It is necessary that parents be in a position to deal with contradictions in the family situation and with whatever innovation is implemented by the education system. The following are some of the contextual influences that may support or hinder parents from being fully involved in the lives of their children during the Foundation Phase:

\subsection{Educational level and income of parents}

According to Mashau (1989:41), the better educated parents normally interact with their children more frequently and endeavour to provide a high level of cognitive stimulation. On the other hand, the child raised in a home where especially the mother does not interact sufficiently with her children, has to fall back on his/her own devices in trying to figure out the meaning of the world.

According to the study undertaken by Fraser (1988:126), children of the parents of the middle-class tend to do well academically because they are motivated to be curious, responsible and autonomous and are encouraged to develop techniques of reasoning. Fraser (1988:127) found in his study that parental education, reading habits, income,occupation and living space are all related significantly to the intelligence quotient and academic performance of their children. In his study, Fraser used the expression "parental level of education" to refer to the education of any parent who has received functional education for at least four years and who can read and write. Jubber (1990:7) echoes that highly educated and occupationally well-positioned parents have the advantage of transmitting to their children the kind of skills, knowledge and attitudes which encourage and facilitate good school performance. Jubber (1990:8) concludes that such parents are generally further fortunate in being able to provide the kinds of equipment, resources, experience and study environment that promote good schoolwork, and they are also able to send their children to the best scools.

The low educational level of parents also affects their socio-economic life. For instance, in homes where the wage is low, and especially in case of unemployment, the family does not always cater for the children's needs. Jubber (1990:4) observed that "family income contrbutes to a child's cognitive development directly and indirectly. Its more direct 
effects relate to such things as the relationship relationship between income and nutrition, health, quality of school attended, preschool education, the quality of the home as an information environment, the value attached to education and the ability of the family to supply the kinds of educational support, equipment and experiences which foster school success." In the same study, Jubber (1990:5) found that children from the poorest homes have proportionately more of their number who are poor performers.

\subsection{Culture of the community}

\subsubsection{Introduction}

Culture is not static. It is a changing entity, influencing the actions of its members and also being influenced by these actions.

Researchers such as Fyfe and Figueroa (1993:19), Kabagarama (1993:14), Lemmer and Squelch (1993:11) and Mabusela (1995:12) agree on the same definition of culture as a system of values and norms, beliefs, rules of conduct, communication, knowledge and dynamism which have dynamism which have been socially constructed and are socially transmitted as part of a group's heritage and as the framework and medium of its life. Lemmer and Squelch (1993:11) further indicate that culture has both implicit and explicit elements: "Implicit elements are discreet and hidden, such as attitudes, values and beliefs. Explicit culture is visible and easily recognisable in aspects such as food, dress and language." Sebidi (1999:54) concurs that culture is forged by human beings in a subject-subject-to-subject relationship with one another and interacting with their environment in the pursuit of food, clothes and shelter.

Many definitions of culture point to the fact that culture is an identified common way of life. therefore, embraces all the aspects of life such as language, gender, roles, religion, behaioural norms and values. Culture is actually the way people live because whatever is contained within a culture constitutes a strategy for survival. It determines the identity of a person. Culture can, therefore, be regarded as a contextual influence in the lives of children during the Foundation Phase. According to Mncwabe (1990:56), in the South African context, culture "... tends to be defined in racial rather than in broader (e.g. social class) terms."

Culture could influence the dynamics of the support for learning by parents in the education of their children. The cultural bond offers the child a particular environment. It gives him values and norms according to which he can adapt his life. It also presents the child with the guidance of a cultural-social bond in which he can develop his abilities. It is the application of those abilities that will contribute to the development of his culture. Wyngaard (1994:61) maintains that cultural practices change continuously owing to the impact made by other cultural groups, welfare, economical and technological influences which could sometimes be destructive to the norm and value conceptions of the culture concerned. Wymgaard (1994:62) emphasises that cultural deprivation takes place when the child is suppressed, when the conflict is between the parents and school and when the child is excluded from exposure to enriching cultural moulding influences. However, the learning of effective language usage and the understanding of language, promote the child's learning abilities.

\subsubsection{Language}

Language is communication. Le Roux (1994:44) describes communication as the ability to listen, a means of selfexpression and sensitivity to subtlety and nuances in meaning. Communication is, in fact, the "handle" by which people grasp and hold onto the world. The language of any tribe is a vehicle for transmitting its cultural heritage from generation to generation. Moseley (1996 in Davids 1997:101) declares that "... each language is unique in a deep sense. It is the repository of accumulated thoughts and experiences of people, their metaphors and specialised knowledge, their unique experiences that developed over many lifetimes."

Children from a culture of poverty are impeded by a lack of ability to communicate in the dominant culture. This ability is limited by language deficiency. In addition, the interpersonal communication skills of these children are such that actualisation of their actualisation of their personal ptential is also hampered. They are given scant encouragement and stimulation to develop their potential.

Parents suffering poverty seldom play with and support their children; there is not much purposeful conversation to support their education and training. Holman (1979, in Le Roux 1994:44) states that the parents of these children typically talk to them less often and seldom ask them questions.

Language problems in such children could be the result of a poor linguistic example set by their parents parents. Because their use of language is of a poor quality, the pedagogic discourse lacks quality and scope. If the language used 
in the child's broader environment is also poor, the problem is compounded compounded, and his or her language acquisition will be inadequate for academic demands. This again negatively affects the child's attainment of maturity. Le Roux (1994:45) declares that since language development is determined socially, the inhibiting life-world of children in a poverty-culture has a direct and significant impact on their language usage. Their limited language ability is a reflection of their restrictive circumstances. Inadequate language usage and communication are detrimental to the child's development and again promote the culture of poverty. Language could, therefore, be regarded as one of the contextual influences that could most critically hinder parents from being constructively involved in the education of their children during the Foundation Phase. Directly associated to language development is also the issue of literacy.

\subsubsection{Literacy}

In all African cultures, education was in the past conducted in the oral method. Nothing was written. With the arrival of the missionaries, written text was introduced, but unfortunately most of the parents could not read nor write. Those who could continue their education were mostly men and the highest qualification was usually Standard Six (Grade Eight). The constraints of family illiteracy, semi-lliteracy and literacy on the academic development of South African learners are in evidence to this day.

According to Langer (1987:4), literacy is an activity, a way of thinking, not a set of skills. It is a purposeful activity. People read, write, talk and think about real ideas and information in order to ponder and extend what they know, to communicate with others, to present their points of view, and to understand and be understood.

Singh (1996:312) declares that the term illiteracy indicates the inability to read or to write in any language whereas the term semi-literate denotes the ability to read and write in a very limited way. In the latter case the reading and writing skills are not permanently acquired and, therefore, can be easily lost. Singh (1996:312) adds that five years of formal schooling (Grade Five) are usually regarded as an indicator of basic literacy. Basic literacy is defined as the ability to read and write short simple sentence in the mother toungue and is regarded as a pre-requisite for the attainment of effective functional literacy.

Functional literacy is understood to be the ability to engage in activities where literacy is required for effective functioning within a particular community, as well as enabling the individual to continue to use reading, writing and calculation for the individual's and community's development.

Just as culture affects the intellectual effects of literacy, so too does culture initially affect the process of learning to be literate. To promote the culture of literacy and thus the culture of learning, children need to be given an opportunity in the home to apply their skills and to solve problems. The new curriculum requires that the basic literacy skills and a resource-rich learning environment be made available for children. Hannon (1995:5-6) recognises this and argues that "... literacy is the key to the rest of the curriculum. Virtually all schooling after the first year or two, assumes literacy. This is particularlr so to the extent that children are expected to work independently of teachers, for that requires them to read

worksheets, written directions, reference materials, and so on." This style of learning needs to be reinforced in the home.

A resource-rich environment means a teaching and learning context that exposes learners to a range of diverse sources of information and representations of ideas and views in many forms and languages. It is about being creative to source-free or low-cost, appropriate and locally available learning resources and how they are used in the process of teaching and learning. In a resourse-rich environment, learners, together with their peers, parents and siblings, can dscuss their ideas and pitch their view points in contest against one another. Given this context, learners can develop independent and critical thinking skills and eval;uate matters in a more reasoned manner (Department of Education: 1997a:51). To achieve these outcomes, is to be literate.

According to Wells and Chang-Wells (1992:149), learning is also more effective when:

There is a collaborating group.

There is discussion and debate so that ideas have to be contested.

Learners organise and record their thinking in a logical, coherent and meaningful way.

Wells and Chang-Wells (1992:149) found writing to be more influential than reading because it is through writing, recording and re-presenting that learners process and evaluate information and begin to exercise their critical judgement. To be independent critical thinkers, learners need to acquire basic information processing and application skills rather than organising large quantities of content information that are quickly forgotten or become obsolete.Such skills involve selecting a suitable information source, accessing the relevant information and processing, sorting and organising it so that it is appropriate to the problem. The process should be explicitly supported and ecouraged in the home.

The RSA statistics for 1991 show that there were 3 million persons over the age of of eighteen years who had had 
no schooling whatsoever. Of these, approximately $90 \%$ were Africans and a further 216,000 of Coloured origin (South African Department of Education 1992:120). We find that even today illiterate parents are often not overly involved in their children's education because they cannot read nor write. They do not see themselves as teachers. They leave everything in the hands of teachers.

The culture of literacy and learning in the family is not the only influence on parents' involvement in their children's education. Religion often plays a decisive role as wellReligion The bond between man and God is known as "religion" and determines man's selfhood.

Van Schalkwyk (1990:16) states that "... man's selfhood is the religious root of his existence and this personal one serves as the mainspring for all his other relations, determining the kind of person he is and the way in which he creates culture." Edgell (2005:58) adds that family is a crucial arena for religious education and socialisation of the next generation.

The parent who has his or her own religion introduces the child to the same belief. The young child will thus tend to follow the religion of the parent. The parent will teach the child according to his/her religion. What the parent adores or values, the young child will tend to follw suit. Religion influences the activities that one is involved in. According to Van Schalkwyk (1990:16), "...religion constitutes the deepest and most fundamental determining force or influence on all cultural activities of man and the community."

The child's need finds satisfaction not only in his personal religious experiences, but also in the common religious practice. According to Wyngaard (1994:60), religion provides the child with "... a large measure of security and, therefore, makes it possible for emotional stability and the creation of personal self-assurance, the moral values that give direction to the moral development and choices of the child and future expectations in the transcendental, that promote purposefulness and give meaning to his imminent existence." The religious experience of the child lends itself to educational activity because religion in itself moulds the character (Zhai, Ellison, Stokes, \& Glenn 2008:381). Religion is advantageous to education in establishing positive views and positive personality characteristics.

Therefore, the child's behaviour, thinking and attitudes could be positively influenced by his or her religion. The child whose parents are not religiously inclined could, on the other hand, tend to lack views and personality characteristics

\subsubsection{Family size}

The size of the family has an influence on the scholastic achievement of children. The larger the family, the poorer the educational performance of children will be (Mwamwenda 1995:29). He emphasises that this is partly due to the necessary reduction that such increases imply in the attention that children receive from their parents as well as a reduction in living standard, living space, learning resources and privacy. Parents with one or two children will have an opportunity to lavish more love, care and attention on their children. They are likely to be able to provide their children with the necssary resources and rake them on educational outings. Children from such families will benefit more and ultimately they will become independent and responsible adults.

Among Africans in South Africa, generally many families stay with their relatives such as grandparents, uncles, aunts, nephews, nieces and cousins. Children from such families do not enjoy many of the benefits of focused motherly/fatherly love. According to Nhlapo (1997:20), from the moment when children from large families start school, they appear to get less encouragement from their parents, which could eventually be one of the reasons why such children tend to do less well academically.

\section{Physical Dimension}

Physical care of the Foundation Phase learners by the parents should be considered since the children are still developing and it is their parents' role to help and support them during the development of new skills.

\subsection{General principles}

Generally speaking, the more practice and opportunity a child receives in a physical or motor skills, the more adept he is likely to become, so that every encouragement should be given to children in the development of new skills. According to Lally (1991:9), children are vulnerable and need support from both parents. Azar (1989, in Hiatt 1996:81) emphasises that young children are less able to communicate their needs, thoughts and feelings, thus leaving room for a variety of parental interpretations of what they seem to require. Physical care of children includes nutrition, haelth, safety and 
supervision by parents.

The need for food is among the most basic human needs. According to Barrett and Frank (1987, in Cooper 1991:7), adequate food is needed in order to survive, to grow and reproduce, to carry out physical work, and to learn from one's experiences. Children should be encouraged to use the senses to explore the way food looks, feels, tastes and smells. They should also be encouraged to aet all of the food provided and complete the meal. Food preparation is the responsibility of parents. Growing children need a balanced diet, sustaining breakfast and mid-morning snack to provide the necessary enery for optimum engagement and learning in school.

Children depend on adults to provide them with safe and healthy places to live. Whether at home or in community settings, sanitary conditions must prevail. Areas for acts such as food preparation asnd service, toileting and bathing, and sleeping must be kept clean and safe. Parents must see to it that the play area is free of all hazardous objects and check whether toys and equipment are in safe working order. According to Draper and Draper (1987:84), toys and equipment should be stored in a closed and locked area when not in use and be kept away from the traffic pattern of children. Children must be prevented from playing in the streets and protected from child abuse in all its forms.

Healthy children are cheerful. In the Foundation Phase, they appear to enjoy being with others and cope with problems successfully most of the time. Such children like to explore and try out new ideas.

Draper and Draper (1990:74) declare that such children show enough strength for body size while playing with push, pull, lift and carrying toys. They also enjoy activities which require lots of body movement. Nhlapo (1997:21) adds that a healthy child enjoys playing alone at times and smiles or responds in positive ways to other children and adults. The attention span is long enough to enjoy interesting activities.

\subsection{Effect of problems/inadequacies}

Children who are not taught the sensory and motor skills that are needed in their future life and given sufficient opportunity to practice these, may be affected. These children may then be unable adequately to perform the activities expected of them. Such neglect can affect children's school activities as well as learning performance. Children who are deprived of such activities may experience feelings of inferiority, unhappiness and rejection.

If children are not given enough and proper food to eat, or if they are otherwise neglected or physically abused at home, their emotional and cognitive growth will probably be affected. According to Ferron (1986:4) and Etaugh and Rathus (1995:288), there are two types of malnutrition, namely, quantitative malnutrition, which refers to a lack of the right amount of food, and qualitative malnutrition, which refers to a lack of certain minerals and and vitamins in the diet. A lack of vitamin B, for example, produces the disease known as Pellagra which permanently injures the central nervous system. Malnutrition also cause loss of energy and it is detrimental for brain development. Recent research has emonstrated that other things being equal, inadequately nourished mothers tend to give birth to less intelligent children than those who have well balanced diets (Etaugh \& Rathus 1995:287). According to Klein (2011:19), malnutrition is the condition tha occurs when the body does not get enough nutrients.

According to Etaugh and Rathus (1995:288), many children and adults consume excessive amounts of sugar and salt, which can be harmful to their health. If children are repeatedly exposed to sweet and salty food, preference for both will increase during childhood. Etaugh and Rathus (1995:289) emphasise that children should be given food in the way parents want them to accept it in the future. Parents serve as role modeliis in the development of food preferences. Rozin (1990, in Etaugh \& Rathus 1995:289) declares that if a parent displays an obvious dislike for vegetables, children may develop a similar dislike .

Insufficient and inadequate food will cause young children to fall ill easily, and this can in turn make them feel neglected and helpless. Life could even become meaningless to children who are not well nurtured. Nhlapo (1997:19) emphasises that a hungry, thirsty, tired or sleepy child, or a child in school who has been sitting quietly for too long, is not likely to learn adequately, nor is the child who has urgently to go to the toilet, or who is working in a classroom that is illventilated or too hot or too cold.

\section{References}

Cooper, D. C. 1991. The foundations of effective development: Proactive involvement of the educational psychologist. M.Ed Dissertation. Pretoria: University of Pretoria.

Davids, L. 1997. Shaping Africa's future through innovative curricula. National Institute for Educational Development. Centralisation and Identity: Sub-Regional Cooperation. Namibia: Gausburg McMillan Publishers

Draper, W. 1990. The Encylopaedia of Human Development and Education. Emotional Development. New York: Pergamon Press. 
Edgell, P. A. 2005. Religion and Family in a Changing Society. Princeton, NJ: Princeton University Press.

Etaugh, C. \& Rathus, S.A. 1995. The world of children. New York: Harcout Brace Publishers.

Felkins, P. K., Chakiris, B. J. \& Chakiris, K. N. 1993. Change Management: A model for effective organizational performance. Quality Resources. New York: White Plains.

Fraser, E. 1988. Home environment and the school. London: University of London.

Ferron, O.M. 1986. Developmental Psychology. Alice: Lovedale Press.

Fyfe, A. \& Figueroa, P. (Eds.). Education for cultural diversity: The challenge for a new era. London: Routledge.

Hiatt, F. L. 1996. Politics of Education association yearbook. Parents and children: Representations of family understanding parents and teachers internal working models of their roles in children's lives. New York: John Willey \& Sons, Inc.

Jubber, K. 1990. The home and family environment and its impact on school performance. South African Journal of Sociology, 21(1): 1519.

Kabagarama, D. 1993. Breaking the ice: A guide to understanding people from other cultures. Boston: Allyn \& Bacon, Inc.

Klein, S. 2011. Protein-energy malnutrition. In: Goldman L, Schafer, A.I,eds. Goldman's Cecil Medicine. 24th ed. Philadelphia, Pa: Saunders Elsevier.

Lally, M. 1991. The nursery teacher in action. London: Paul Chapman Publishing Limited.

Landman, W. A. \& Bodenstein, H. C. A. 1994. Basic concepts in research methodology. Halfway House: Orion.

Langer, J. A. 1987. Language literacy and culture: Issues of society and schooling. U. S. A.: Ablex Publishing Corporation.

Lemmer, E. \& Squelch, J. 1993. Multicultural education: A teacher's manual. Pretoria: Southern Book Publishers (Pty) Ltd.

Le Roux, J. 1993. The black child in crisis: A socio-educational perspective, Vol 1. Pretoria: JL van Schaik.

Mashau, A. 1989. Parental responsibility in the education of the Tsonga child. Pretoria: University of South Africa.

Mncwabe, M. P. 1990. Phylosophy of education and a conflict of beliefs in the South African educational scene. Paidonomia, 16(2(: 3945.

Mwamwenda, T. S. 1995. Educational Psychology. An African perspective, (2nd ed.) Durban: Butterworths.

Nhlapo, R. V. 1997. The role of parents. Mini M .Ed Dissertation. Johannesburg: Rand Afrikaans University.

Sebidi, L. 1990. Dynamics of culture. Tribune (June): 54. African Renaissance Series.

Singh, G. 1996. A model for the provision of career education within community colleges with special reference to KwaZulu Natal. PhD Thesis. Pretoria: University of Pretoria.

South African Department of Education. 1997a. Curriculum 2005: Lifelong Learning for the 21st century. Pretoria: Department of Education.

Van Schalkwyk, O. J. 1990. Ouerbetrokkenheid: ‘n Handleiding vir die onderwyser. Pretoria: Alkanto Uitgewers.

Wells, G. \& Chang-Wells Gen-ling. 1992. Constructing knowledge together: Classroom as centres of inquiry and literacy. Portsmouth, $\mathrm{NH}$ : Heinemann.

Wyngaard, A. T. 1994. Child and society: A socio-pedagogical perspective, (1st ed.). Durbanville, South Africa: Wachwa Publishers.

Zhai, J. E., Ellison, C. G., Stokes, C. E. \& Glenn, N. D. 2008. 'Spiritual, but not Religious:' The impact of parental divorce on religious and spiritual identities of young adults in the United States, Review of Religious Research 2008, Vol 49 (4): 379-394. 